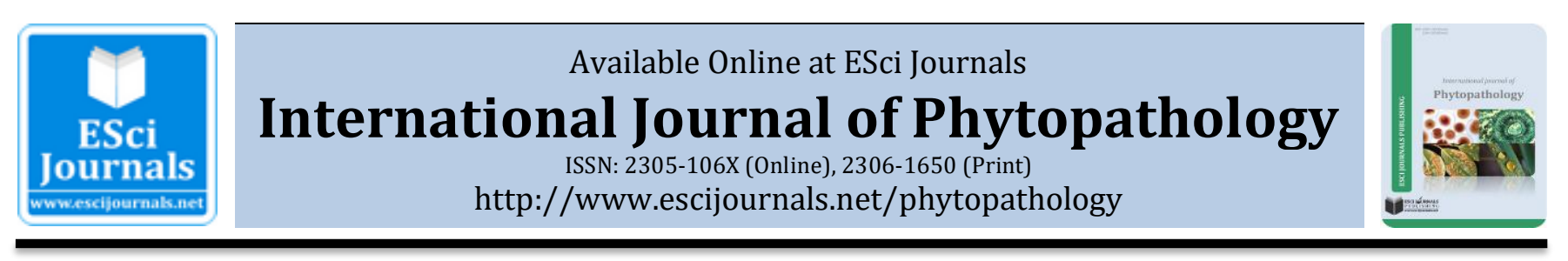

\title{
BACTERIAL WILT CAUSED BY RALSTONIA SOLANACEARUM IN ETHIOPIA: STATUS AND MANAGEMENT APPROACHES: A REVIEW
}

\author{
aHenok Kurabachew, bGetachew Ayana \\ a Hawassa University: College of Agriculture, P. O. Box 05, Hawassa, Ethiopia. \\ b Ethiopian Institute of Agricultural Research: Melkasa Agricultural Research Center P.O.Box 436 Adama, Ethiopia.
}

\section{A B S T R A C T}

Bacterial wilt caused by Ralstonia solanacearum is one of the most devastating plant diseases of economically important crops mainly Solanaceous family such as tomato, potato, pepper and eggplant. These crops play a significant role primarily as sources of income and food security for the small scale farming community in Ethiopia. The occurrence of bacterial wilt disease in Ethiopia was reported in 1956 and is known to cause significant yield loss on different Solanaceous crops in different parts of the country. On the basis of conventional characterization and classification, the strains of $R$. solanacearum found in Ethiopia have been identified as biovar 1 and 2 . Recent characterization of $R$. solanacearum strains based on phylotype grouping using multiplex PCR and partial endoglucanase gene sequencing identified the occurrences of phylotype II and III. The association of biovar and phylotyping schemes indicated that phylotype II comprises only biovar 2, and phylotype III comprises strains of biovar 1 and biovar 2. The importance of the disease on Solanaceous crop is increasing from time to time specially in potato producing areas of the country. Apart from Solanaceous crops, the disease has also been posing a catastrophic damage to ginger production. Latently infected ginger rhizomes and potato seed tuber and decreasing of land holdings that limit crop rotation have contributed to the wider spread of the disease. In this review attempt has been made to summarize relevant scientific studies on this economically important disease in Ethiopia as well as its different disease management options, challenges and future considerations. Because, there is no single effective control measure against the target pathogen so far, a well-coordinated effort is required to develop an integrated disease management program that will help to minimize the damage and yield loss caused by the disease.

Keywords: Bacterial wilt, Biovar, Phylotype, Race, R. solanacearum, Solanaceous crop.

\section{INTRODUCTION}

Bacterial wilt caused by Ralstonia solanacearum is one of the most devastating plant diseases of economically important solanaceous crops worldwide in general, and in Ethiopia in particular. There are over 3000 species that belong to the family Solanaceae, which is the third most important plant family (exceeded only by grasses and legumes). It comprises a number of economically important crops, such as tomato, potato, pepper and eggplant (Knap et al., 2004).

Solanaceous crops production such as potato, tomato and pepper, etc., play a significant role in developing country like Ethiopia as a source of income and

* Corresponding Author:

Email: henok.k5 @gmail.com

(c) 2016 ESci Journals Publishing. All rights reserved. improved social and nutrition status. In addition, they provide employment opportunities as their management being labor intensive, thus production of these commodities should be encouraged in labor abundant and capital scarce countries like Ethiopia. Currently, the majority of the horticultural crops product in Ethiopia comes from smallholder farms (Haverkort et al., 2012). There are different abiotic constraints that limit the productivityof these crops such as low levels of input use (fertilizer, pesticide, improved seeds, etc.), low levels of irrigation, soil degradation and soil erosion, inadequate agricultural research and extension, and constraints in market development. Among the biotic constraints bacterial wilt, which is caused by Ralstonia solanacearum (Yabuuchi et al.. 1995) is one of the most important diseases that limit its production in Ethiopia. 
The disease poses a serious damage to the cultivation of many Solanaceous crops such as tomato, potato, tobacco, pepper and eggplant in tropical, sub-tropical and temperate regions (Hayward, 1991).

The Pathogen: Ralstonia solanacearum: Bacterial wilt caused by Ralstonia solanacearum (Yabuuchi et al., 1995) [syn. Pseudomonas solanacearum (Smith 1896) has been described as one of the most devastating plant pathogen mainly in tropical, subtropical and some warm temperate regions of the world (Buddenhagen and Kelman, 1964; Hayward, 1991). The host range of $R$. solanacearum is unusually wide for a plant pathogen, affecting over 450 host species in 54 botanical families (Wicker et al., 2007). Some of its economically important hosts are tomato, potato, tobacco, banana/plantain, cowpea, peanut, cashew, papaya, and olive. There are also weed and asymptomatic hosts that may play a role in the survival and persistence of $R$. solanacearum (Hayward, 1994; Moffett and Hayward, 1980). In Africa, the pathogen is found in Angola, Burkina Faso, Burundi, Cameroon, Congo, Ethiopia, Gabon, Gambia, Kenya, Madagascar, Malawi, Mauritius, Mozambique, Nigeria, Réunion, Rwanda, Senegal, Seychelles, Sierra Leone, Somalia, South Africa, Swaziland, Tanzania, Tunisia, Uganda, Zaire, Zambia, and Zimbabwe (OEPP/EPPO, 2004) causing significant yield loss.

Ralstonia solanacearum is a highly heterogeneous bacterial species. The species is divided into five races based on host range (Buddenhagen et al., 1962; He et al., 1983; Pegg and Moffett, 1971) and into six biovars according to its ability to metabolize three sugar alcohols and three disaccharides (Hayward, 1964; Hayward, 1991; Hayward, 1994). Both classifications lack an exact concordance with the genetic background of the complex members. Therefore, molecular-based assessment of the genetic diversity of $R$. solanacearum employing restriction fragment length polymorphism analysis resulted in two clusters of strains as divisions 1 Asiaticum and 2 Americanum (Cook and Sequeira, 1994). Recently, a phylogenetically meaningful classification scheme was developed based on DNA sequence analysis (Fegan and Prior, 2005; Fegan and Prior, 2006). This scheme divides the complex species into four phylotypes that broadly reflect the ancestral relationships and geographical origins of the strains. Accordingly, phylotype I, II, III and IV strains are originated from Asia, America, Africa, and Indonesia, respectively. The phylotypes are further subdivided into sequevars based on the sequence of the endoglucanase (egl) gene (Fegan and Prior, 2005; Fegan and Prior, 2006). $R$. solanacearum R3bv2 strains belong to phylotype II and sequevars 1 and 2 Fegan and Prior (2005). This phylotyping scheme proposed by Fegan and Prior (2005) is consistent with the former phenotypic and molecular typing schemes and adds valuable information about the geographical origin and in some cases the pathogenicity of strains.

Epidemiology and Survival of the Pathogen: $R$. solanacearum enters roots through wounds made by transplanting, cultivation, insects, or certain nematodes and through natural wounds where secondary roots emerge (McCarter, 1991). Once inside the host, the bacterium has an affinity for the vascular system, where it multiplies rapidly, filling the xylem with bacterial cells and slime. After infection is established it also moves up through the vascular system, the xylem, and finally blocks water transportation, which causes wilting (Hayward, 1991; Wang and Lin, 2005). Typical symptoms of bacterial wilt can be observed few days after infection, such as wilting and later yellowing, dwarfing and finally irreversible, sudden wilting and death of plants, caused by invasion of large quantities of bacterial cells and their exopolysaccharide slime in xylem vessels. Death of plant cell is caused by degradation of vessels and adjacent tissues (Buddenhagen and Kelman, 1964; Hayward, 2000). Further symptoms of bacterial wilt represent discoloration of the vascular system from pale yellow to dark brown and droplets of milky bacterial ooze exuding from affected tissue (McCarter, 1991). Subsequently, $R$. solanacearum cells are set free into the soil from roots or collapsed stems that spread to roots of adjoining plants or to fulfill the saprophytic part of its life cycle (Denny, 2006). The symptoms of bacterial wilt vary due to the diverse nature of the pathogen in colonizing various host plants. There are many bacterial wilt symptoms; however, the typical symptom on tomato is a flabby appearance on the youngest leaves usually at the warmest time of the day, 2 to 5 days after inoculation with $R$. solanacearum. Depending on the environmental conditions, wilting of the whole plant may follow rapidly due to reduced sap flow caused by the presence of large amounts of $R$. solanacearum cells and their exopolysaccharide slime in xylem vessels (Vasseet al., 1995). Plants later collapse and die due to further degradation of vessels and surrounding tissues. If the 
conditions are less favorable for the pathogen, the disease develops less rapidly, characterized by stunting and the development of adventitious roots. The favorable conditions for development of bacterial wilt in tomato is described by Wang and Lin (2005) high temperature and moist soils but develops slowly when the soil temperature is lower than $20{ }^{\circ} \mathrm{C}$ or soil moisture is low. When the stem is cut, vascular tissues occur in a brown discoloration and white or yellowish bacterial ooze may be visible (OEPP/EPPO, 2004). The bacterium returns to the soil after plant death, living as a saprophytic organism until it infects a new host plant.

Transmission and dissemination of the pathogen occur through several means. The bacterium can be carried over long distances on vegetative propagating materials surviving about 2-3 years (Hayward, 1991; Coutinho, 2005). Vegetative organs are undoubtedly an important source of inoculum and contribute to short and long distance dispersal of the pathogen. $R$. solanacearum, also survives in wet soil, deep soil layers $(>75 \mathrm{~cm}$ ) (Van Elsaset al., 2001), contaminated irrigation water, on wooden materials (several days), metal (several weeks) and rubber (several months), in chicken and cattle manure (2-4 weeks) and in waste from the potato processing industry (1-2 months), as well as in latently infected potatoes and tomato seeds and infected potato tubers (Hayward, 2000; NAPPO, 2001). Crop residue left in the fields that were infected by $R$. solanacearum also serves as source of disease inoculum in the field (Wang and Lin, 2005). Insects have been also considered as vectors and a high potential for natural spread of race 2 , which is known to be transmitted by insects (Olsson, 1976; Elphinstone, 1998). Hence, extensive host range, wide distribution and long saprophytic survival in the environment make the control of the disease caused by R. solanacearum more difficult.

Economic Importance of Bacterial Wilt: The world's population is increasing every year in order to meet the demands of an ever increasing human population, the global crop production should double by 2050; however, current estimates are far below what is needed (Ray et al.,2013). Plant diseases, insects, and weeds decrease the production of crops worldwide by $36 \%$, and diseases alone have been shown to reduce crop yield by $14 \%$ (Agrios, 2005). Thus, control of plant diseases contributes to increased crop production. Among plant diseases, soil-borne diseases are considered to be more limiting than seed-borne or air-borne diseases in the production of many crops and account for $10-20 \%$ of yield lossesannually (USDA, 2003). Mansfied et al. (2012) reported the top ten bacterial species based on their scientific and economic importance in plant diseases are: i) Pseudomonas syringae pathovars, ii) Ralstonia solanacearum, iii) Agrobacterium tumifaciens, iv) Xanthomonas oryzae pv. oryzae, v) X. campestris pathovars, vi) $X$. axonopodis pathovars, vii) Erwinia amylovora, viii) Xylella fastidiosa, ix) Dickeya (former Erwinia) (dadantanii and solani), and x) Pectobacterium (former Erwinia) carotovorum (and Pectobacterium atrosepticum). Accordingly, R. solanacearum is ranked as the second most important bacterial pathogen.

Bacterial wilt cause severe yield losses on different Solanaceous crops in different parts of the globe for instance, $50-100 \%$ on potato in Kenya (Muthoni et al., 2012), 88\% of tomato farms affected by bacterial wilt in Uganda (Katafiire et al., 2005), 70\% on potato in India and varying degree losses in many potato growing countries of the world (APS, 2005). Bacterial wilt affected $95 \%$ of tobacco farm field in some counties of South Carolina and resulting in an estimated total losses of \$40 million in both North and South Carolina in 1998 (Fortnum, 2001). In Ethiopia percent wilt incidence of bacterial wilt is as high as 63\% (Bekele, 1996) on potato, $55 \%$ on tomato (EARO, 2002) and $100 \%$ on pepper (Assefa et al.,2015) were recorded in major potato, tomato and pepper growing areas of Ethiopia but yield loss were not quantified (Bekele et al.,1996). In case of potato, since most wilted potato plants do not give marketable tube, crop yield losses from the disease could be very high under Ethiopian conditions. The pathogen has been known to have a high survival and damaging risk to many economic crops and other vegetation in Ethiopia. Hence, there is a need for proper management against this pathogen.

The considerable economic losses caused by the pathogen ascribed to its persistence, wide host range and its broad geographical distribution in tropical, subtropical and some warm temperate regions of the world (Elphinstone, 2005). Though there is no general information on economic impacts worldwide, the pathogen causes substantial yield losses depending on host, cultivar, climate, soil type, cropping practices and pathogen strain (Elphinstone, 2005). Losses of about $75 \%$ in potato due to bacterial wilt have been described, whereas in tomato, being one of the most susceptible crops, $R$. solanacearum can result in total destruction of 
the harvest (Elphinstone, 2005; Hayward, 2000; Hayward, 2005). Losses are rising because agriculture is extending into countries where susceptible crops have not been cultivated before (Persleyet al., 1986). In addition to significant yield losses, bacterial wilt is also responsible for indirect damage such as interference with land usage and disposal of susceptible crops. The presence of $R$. solanacearum in fields discourages the planting of many vegetables on family farms and home gardens, which leads to a considerable reduction in food source [(Kelman, 1998);(Hayward, 2000)]. In areas, where the organism has quarantine status, considerable economic losses can result from the prescribed destruction of entire infected crops and restriction of further cultivation on contaminated land (Elphinstone, 2005).

Bacterial Wilt in Ethiopia: The presence of bacterial wilt in Ethiopia was first reported on potato and eggplant in Keffa region (South West Ethiopia) (Stewart, 1956). However, Stewart and Dagnachew (1967) through an index of disease in Ethiopia had reported the occurrence of the bacterial wilt on potato, tomato and eggplant in Keffa and on potato in Showa and Arsi region (Central Ethiopia). In mid 1970s, the disease was not considered as a serious threat to potato production in Ethiopia except in very limited areas like Wendogenet and Shashemene. In the mid-1980s, however, the disease was recorded in many regions such as Kefa, Sidamo, Welega, Welo, Gamugofa, Shewa and Alemaya that eventually changed its status. Studies indicated that bacterial wilt on potato and tomato crops in Ziway (South Ethiopia) and on potato in Ambo Bako and Guder (Central Ethiopia) (SPL, 1981) and sometime in the past the disease caused heavy losses in potato tuber seed multiplication Tsedey Farm from the Central Ethiopia, as a result of the commercial farm was abandoned. Latter in mid 1990s, bacterial wilt was considered as one of the most important diseases that limits potato production (Bekele and Berga, 1993).

Moreover, Yaynu (1989) indicated that bacterial wilt is an important disease of potato and tomato in different parts of Ethiopia. Lemessa and Zeller (2007) also reported bacterial wilt was attacking pepper plant in some areas of Ethiopia. Records on the occurrence of bacterial wilt disease increased with elevated production of potato in the country with time. In early days, when potato was grown in small acreage, the distribution of the disease was limited to only areas such as Wendogent and Shashemane (South East Ethiopia). Since Shashemane area was of the major sources of seed potato for many years, bacterial wilt was likely spread through the expansion seed exchange and repeated potato cultivation in the country. Still, the country has great potential for potato expansion (Gebremedhin et al., 2006) and potato acreage is increasing every year with the danger of this disease also rises with this expansion. Presently, bacterial wilt in potato has been reported from many parts of the country such as Kefa, Gamugofa, Sidamo,Welega, Welo, Shewa, Arsi, Alemaya, Gojam, and Tigray (Stewart, 1956; Bekele, 1996; Gebremedhin et al.,2006). Furthermore, percent wilt incidence of bacterial wilt as high as $45 \%$ was reported by Yaynu and Korobko (1986) and 63\% by Bekele (1996) on potato and $55 \%$ on tomato (EARO, 2002) from major potato and tomato growing areas of Ethiopia indicating the loss the disease can cause. Recently, Assefa et al. (2015) reported 100\% incidence of bacterial wilt on hot pepper in Bako Tibbe and Anno district (West Shewa) Ethiopia. In addition Bekele et al. (2011) reported bacterial wilt incidence as high as $25 \%$ on potato in Amhara regional state (West Gojam zone and North Gonder administrative zone). This indicates the fast distribution of the pathogen from Southern and Central Ethiopia to the Northern Ethiopia where the pathogen was not common possibly through latently infected potato tuber. Thus, the case of bacterial wilt getting worse due to the emergence of highland strains which make the disease to be more economically important and affect the expansion of potato industry in the country. Currently, the disease is gaining importance especially in the Ethiopian potato industry due to several reasons such as: lack of well-developed seed system that certifies and regulate the distribution of good quality seed potato in the country; absence of quarantine system to safe guard new (disease-free) areas and susceptible plant commodities from bacterial wilt invasion; cultivation of new susceptible plant species has started and the bacterium infects many important export commodities due to less pest management practices in the country (Dereje et al., 2013). In very recent years bacterial wilt has been reported to cause severe threat to ginger production in Ethiopia. Tariku et al. (2016) reported that a severe outbreak of ginger wilt disease identified as bacterial wilt caused by Ralstonia solanacearum with disease incidence of $80-100 \%$ in Southern Ethiopia. Generally 
the significance of the disease increasing from time to time specially in potato production because of latently infected seed potatoes and decreasing land holdings that limit crop rotation (Bergaet al., 2000).

The diversity of the pathogen in Ethiopia was studied and the strains that occur in Ethiopia belong to race 3 of biovar 2 and race 1 of biovar 1 of $R$. solanacearum (Yaynu, 1989, Lemessa et al., 2010). Recent characterization of $R$. solanacearum strains based phylotype grouping using multiplex PCR and partial endoglucanase gene sequencing identified the Ethiopian strains to be phylotype II and III. The association of biovar and phylotyping schemes indicated that phylotype II consisted only biovar 2, and phylotype III comprises strains of biovar 1 and biovar 2 (Getachew, 2009).

Bacterial Wilt Management Approaches: Management of bacterial wilt is caused by $R$. solanacearum is difficult once it has established in the soil. This is because wide host range, long survival in the soil, spread in many ways (including planting materials, irrigation water, farm implements and vectors), survives in vegetation as latent infection and genetically diverse strains (APS, 2005; EU, 2003). However, knowing these features of the disease is quite useful to analyze conditions that determine disease development and plan sound disease management strategy. Up to now there is no single control effective measure against the pathogen (Lemessa and Zeller, 2007; Bekele and Berga, 2001). However, some level of bacterial wilt control has been possible through use of a combination of diverse methods. These methods include host resistance, agronomic practices, cultural practices, biological control, chemical control and integrated disease management (IDM).

Host Resistance: Developing cultivars that are resistant to bacterial wilt is considered to be the most economical, environmentally friendly, and effective method of disease control. Breeding for resistance to bacterial wilt has been concentrated on crops of wide economic importance such as the tomato, potato, tobacco, eggplant, pepper, and peanut (Boshou, 2005). The stability of resistant varieties is highly affected by pathogen strains, temperature, soil moisture, and presence of root-knot nematodes, host pathogen interaction, breeding methodology, and genetic linkage between resistance (Boshou, 2005; Elphinstone 2005; Wang and Lin, 2005). Therefore, increasing varietal resistance in the framework of an integrated approach may be the most suitable approach to control the disease (Denny, 2006). Getachew et al. (2009) evaluated the resistance tomato against the highly aggressive $R$. solanacearum strain originated from Ethiopia. He found that six resistant, eleven moderately resistant whereas most genotypes including all tomato cultivars commonly grown in Ethiopia were found highly susceptible. Resistant plants colonized and invaded by $R$. solanacearum showed tolerance to the disease. Nakahoet al.(2004) revealed that bacterial multiplication in the stems of resistant tomato plants was suppressed due to limited pathogen movement from the protoxylem or primary xylem to other xylem tissues. Furthermore, Dahal et al. (2010) elucidated the molecular interactions in the cell walls of resistant and sensitive plants inoculated with $R$. solanacearum using a proteomic approach.

Agronomic Practices: Cultural practices, if properly used, can reduce the incidence and severity of bacterial wilt. Crop rotation with non-susceptible crops reduces soil borne populations of the bacterium (Bekele and Berga, 2001). Appropriate rotation period and non-host break crops should be identified and used. Shifting planting dates to cooler periods of the year can help escape the disease. While continuous cropping with the same susceptible host plant may end up in the establishment of specific plant pathogenic populations, thus crop rotation breaks this detrimental effect and result in the reduction plant diseases caused by soil borne pathogens (Janiver et al., 2007). In line with this Katafire et al. (2005) found that rotating potato cultivation with wheat, sweet potato, maize, millet, carrots, sorghum, or phaseolus beans reduced the incidence of wilt by 64 to $94 \%$ while the yield of potato was 1 to 3fold higher than that of mono-cultured potato. Similarly, the onset of bacterial wilt was delayed by 1 or 3 weeks and wilt severity was reduced by $20-26 \%$ when a susceptible tomato variety was grown after corn, lady's fingers, cowpea, or resistant tomato (Adhikari et al., 1998). Uses of soil amendment for the control of bacterial wilt have been also evaluated in some areas with some successes (Michel and Mew, 1998). Organic amendments to soil have direct advantageous impacts on plant health and crop productivity through improving the physical, chemical, and biological properties of soil, which can have positive effects on plant growth (Bailey et al., 2003).The degradation of organic matter in soil can directly affect the viability and survival of a pathogen by restricting 
available nutrients and releasing natural chemical substances with varying inhibitory properties and it also increases soil microbial activity thereby enhances the likelihood of competition effects in the soil (Bailey et al., 2003) and stimulate the activities of microorganisms that are antagonistic to pathogens (Akathar and Malik, 2000). In line with this Lemaga et al. (2001) reported soil amendment with organic materials (Sesbania sesbana and Leucaena diversifolia) either singly or combined with inorganic fertilizer reduced wilt incidence and increased potato tuber yield. Furthermore, Getachewet al. (2011) have reported that application of silicon fertilizer and sugarcane bagasse (an alternative silicon source) significantly reduced the bacterial population and wilt incidence and increased tomato fruit yield. Silicon amendment has significantly reduced bacterial wilt incidence and enhanced the host resistance in tomato which was attributed to an induced resistance (Dannon and Wydra, 2004; Diogo and Wydra, 2007).Yadessa et al. (2010) also reported that soil amendments with coco peat, farmyard manure (FYM) compost and green significantly reduced bacterial wilt incidence by $81 \%$ and enhanced tomato yield compared to un-amended soil. This could be mainly due to improvement in soil physicochemical characteristics and microbial activity of the amended soil to the advantage of crop growth. This suggests that soil amendment would be an interesting option to manage $R$. solanacearum in the major Solanaceous crop growing regions of Ethiopia. Furthermore, previous study indicated that application of fertilizers reduced the incidence of bacterial wilt. In line with this, Lemaga et al. (2005) reported that the application of nitrogen $(\mathrm{N})+$ phosphorus $(\mathrm{P})+\mathrm{K}$ and $\mathrm{N}+$ $\mathrm{P}$ (application rate of each fertilizer $=100 \mathrm{~kg} \mathrm{ha}^{-1}$ ) reduced bacterial wilt by $29 \%$ and $50 \%$, respectively, and increased the yield of potatoes to $18.8 \mathrm{t} \mathrm{ha}^{-1}$ and $16.6 \mathrm{t}$ $\mathrm{ha}^{-1}$, respectively, which was higher than that in untreated controls (11.2 t ha-1).

Preventive methods are essential for maintaining fields that are free of bacterial wilt. $R$. solanacearum is a soilborne bacterium and may survive for prolonged periods in soil, water, and plant materials (Lopez and Biosca, 2005). Thus, to keep environment free of this pathogen, it is important to clean seeds, soil, water, and tools in order to improve crop production by preventing this disease. The use of healthy seeds that are free of pathogen is the most economical, environmentally friendly and effective method for disease control. Bekele et al. (2011) indicated bacterial wilt incidence as high as $25 \%$ in farmers' fields in four major potato growing administrative zones in the west Amhara sub-region of Ethiopia. Latent infection by R. solanacearum was found in various potato fields, including experimental plots, farmers' seed potato production fields (Bekele et al., 2011). This indicated the fast distribution of the pathogen from Southern and Central Ethiopia to the Northern Ethiopia where the pathogen was not common, suggesting the need to consider strict quarantine measure and restrict the free movement of seed tubers.

Biological Control: The use of rhizosphere resident microbial antagonist is noted as a promising approach in the control of plant disease. The rhizosphere is a habitat in which several biologically important processes and interactions takes place primarilydue to theinflux of mineral nutrients from accumulation of plant roots exudates through mass flow and diffusion (Bias, 2004). Currently, interest in biological control plant disease has increased due to public concerns over the use of chemicals (Whips, 2001). This is mainly due to the promising characteristics of the biological control agent's such as : potentially self-sustaining, spread on their own after initial establishment, reduced input of nonrenewable resources, and long-term disease suppression in an environmentally friendly manner (Whipps et al., 2007). Recent studies have indicated that biological control of bacterial wilt could be achieved using various species of antagonistic rhizobacteria such as Bacillus cereus, Pseudomonas putida, Bacillus subtilis, Paenibacillusmacerans, Serratiamarcescens, Bacillus pumilis and Pseudomonas fluorescens which was isolated from rhizosphere soil sample collected from potato and tomato rhizosphere from Ethiopia (Kurabachew et al., 2007; Lemessa and Zeller, 2007; Alyie et al., 2008; Kurabachew and Wydra, 2013). Moreover, CiampiPannoet al. (1989) has proved the use of antagonistic bacteria to control $R$. solanacearum under field condition. Potential biological agents used to control bacterial wilt caused by $R$. solanacearum include avirulent mutant of R. solanacearum Dong et al. (1999), genetically engineered antagonistic bacteria Kang et al.(1995) and some naturally occurring antagonistic rhizobacteria such as Bacillus cereus, Pseudomonas putida, Bacillus subtilis, Paenibacillus macerans, Serratia marcescens, Bacillus pumilis and Pseudomonas fluorescens (Kurabachew et al., 2007; Lemessa and Zeller, 2007; Alyie et al., 2008; Kurabachew and Wydra, 
2013). Recently, Biratu et al (2013) also reported that the potential of actinobacteria for the biological control of the pathogen through the in vitro evaluation of actinobacteria isolates isolated from three districts of West Showa Zone, Ethiopia which can be used as one component of the integrated management of the bacterial wilt disease. The possible suppression mechanisms of these species (biological control agents) are competition, induction of plant-mediated systemic resistance, antibiosis, siderophore production and production of enzymes that degrade the cell wall. Therefore, the evidence presented here is suggestive of the potential of the Ethiopian isolates as biological control agents against bacterial wilt by exploiting the interaction between rhizosphere microorganisms. Generally, plant protection rendered this way can be maximized by combining different methods in an integrated disease management approach such asresistant variety, phyto-sanitation, bio-control and clean seed.

Chemical Control: Several management strategies were advocated for the control of bacterial wilt over the years. However, no single method is effective when applied alone due to the complex nature of the pathogen. Unlikely a single strategy can separately control bacterial wilt in epidemic regions (Saddler, 2005). Pesticides such as algicide (3-[3-indolyl] butanoic acid), fumigants (metam sodium, 1,3-dichloropropene, and chloropicrin), and plant activators generating systemic resistance on the tomato (validamycin A and validoxylamine) have been used to control bacterial wilt. The combination of methylbromide, 1,3dichloropropene, or metam sodium with chloropicrin significantly reduced bacterial wilt in the field from $72 \%$ to $100 \%$ and increased the yield of tobacco and the tomato. The yield of the pesticide-treated tomato was 1.7- to 2.5-fold higher than that of the untreated control (Fortnum and Martin, 1998, Santos et al., 2006). It has been reported that pesticide offered greater net benefit is than other control methods, but this has not always been the case (Edwards-Jones, 2008). For instance, if farmers apply or use pesticides without proper care and knowledge, a percentage of the pesticide may remain in the environment for many years (Gadeva and Dimitrov, 2008), become a contaminant in soil and/or groundwater (Acero, et al., 2008), and be poisonous to farmers (Dasgupta et al.; 2007).Streptomycin application even increased the incidence of bacterial wilt in Egypt
(Faraget al., 1986). Thus, the use of chemicals like antibiotics to control plant pathogens has been seriously questioned because of development of resistant strains, and its use bears a hazard to human health and the environment (OEPP/EPPO, 2004).

Integrated Disease Management: The main goals of an integrated plant disease control program, which is called as integrated pest management (IPM), are to eliminate or reduce the initial inoculums, reduce the effectiveness of initial inocula, increase the resistance of the host, delay the onset of disease and slow secondary cycles (Agrios, 2005).Control of $R$. solanacearum has proven to be a very difficult task not only due to its broad distribution and wide host range, but also the limited means of protection measures available (Geninand Boucher, 2004) and up to now there is no single effective control measure against it. Therefore, this calls for an integrated disease management strategy which is sustainable and ecologically friendly. Various integrated management options for controlling bacterial wilt have been developed in Ethiopia, Kenya and Uganda and are currently being disseminated on-farm in several other PRAPACE member countries (Kinyua et al., 2001). Though the results show positive trends in the management of the disease, bacterial wilt remains a major challenge to potato production in all ASARECA countries. As new varieties become available, their integration in bacterial wilt IDM will be critical.

IDM reduced bacterial wilt disease by $20-100 \%$ in the field or under laboratory conditions, and typically combines two or three methods among cultural practices and chemical and biological methods (Yuliaret al., 2015). In the ad planta experiment the combination of rhizosphere bacteria (B. pumilis.) and silicon with moderately resistant tomato genotype (King Kong 2) significantly reduced the incidence of bacterial wilt by $26.7 \%$ and $50.7 \%$, respectively compared to the pathogen inoculated control (Kurabachew and Wydra, 2014). They also reduced the populations of $R$. solanacearum in mid-stems of the moderately resistant tomato cultivar (King Kong 2) by 5.4\% and 16.9 respectively five days post inoculation, compared to the control. This was supported by enhanced activity of the common defense enzymes such as peroxidase (PO) and phenylalanine ammonia lyase (PAL) (Kurabachew and Wydra, 2014). Thus, it was suggested that silicon increases plant tolerance and induces resistance against $R$. solanacearum because infected plants tolerate the 
existence of the pathogen and continue to grow without showing severe symptoms. With regard to rhizobacteria, reduction of the disease development and $R$. solanacearum population in mid stem of the tomato plant is not due to the direct antagonism between $B$. pumilis and the pathogen. Rather this might be through induction plant mediated systemic resistance by $B$. pumilis which switch on the plant defense mechanism (Kurabachew and Wydra, 2014).

Furthermore, Kurabachew et al. (2013) reported an upregulation of genes involved in signal transduction, defense in moderately resistant tomato genotype primed with rhizobacteria and silicon which proved the induction plant mediated systemic resistance which results in the reduction of bacterial wilt. A higher number of defense related genes were regulated in tomato plant treated with silicon than those with rhizobacteria B. pumilis. Moreover, the combined application of silicon and rhizobacteria reduced wilt incidence by $16.9 \%$ in the King Kong 2 genotype which was less than the disease reduction obtained from the separate application of each elicitor. Similarly, field experiments conducted in Ethiopia showed that application of sugarcane bagasse resulted in the reduction of wilt incidence and populations of $R$. solanacearum in the mid-stems of moderately resistant tomato cultivar (King Kong 2) (Getachew et al., 2011). Furthermore, different researchers have indicated the importance of silicon reduction bacterial wilt incidence in tomato (Diogo and Wydra, 2007). Management of bacterial wilt requires a multi-disciplinary approach (Tusiime et al., 2000) and can only be effective if backed by systematic and continuous community awareness efforts. Generally, it is relevant to select and combine different disease control methods that are practical, economical and also environmentally healthy to control disease and improve yields.

\section{CONCLUSION}

This review reveals that the need for integrated disease management strategy against the devastating bacterial wilt disease specially in Sub-Sahara African country like Ethiopia where the issue food insecurity and fast population growth rate is at the center of the vicious circle of poverty. So far different control strategies have been exercised against the pathogen; however, there is no single effective control measure against the pathogen. Therefore, employing integrated disease management approach is critical. Thus, more effort should be made to improve the soil health, availability of clean planting to minimize the transfer of latently infected planting material from region to region by establishing quarantine center, improve farmers' knowledge on proper production system, etc to control the damage inflicted by the pathogen both at regional and national level.

\section{REFERENCES}

Acero, J.L., F.J. Benitez, F.J. Real and M. Gonzalez. 2008.Chlorination of organo-phosphorus pesticides in natural waters. J.Hazard. Mater. 153:320-328.

Adhikari, T.B. and R.C. Basnyat. 1998.Effect of crop rotation and cultivar resistance on bacterial wilt of tomato in Nepal. Can. J. Plant Pathol. 20:283-287.

Agrios, G.N. 2005. Plant Pathology $5^{\text {th }}$ Edition. Academic Press,San Diego, CA.

Akhtar, M. and A. Malik. 2000. Roles of organic soil amendments

and soil organisms in the biological control of plant-parasitic nematodes: A review. Bioresour. Technol. 74:35-47.

Alyie, N., C. Fininsaand Y.Hikias. 2008. Evaluation of rhizosphere bacterial antagonists for their potential to bio-protect potato (Solanum tubersoum) against bacterial wilt (Ralstonia solanacearum). Biological Control 47: 282-288.

APS (American Phytopathological Society). 2005. Bacterial wilt diseases and the Ralstonia solanacearum species complex. APS Press, American Pytopathological Society. St. Paul,Minnesota, USA.

Assefa, M., W.Dawit, A., Lencho and T. Hunduma .2015.Assessment of wilt intensity and identification of causal fungal and bacterial pathogens on hot pepper (capsicum annuuml.) in Bako Tibbe and Nonno districts of West Shewa Zone, Ethiopia. Intl. J.Phytol. 4 (1):21-28.

Bailey, K.L. and G. Lazarovits. 2003. Suppressing soilborne diseases with residue management and organic amendments. Soil Till. Res.72:169-180.

Bekele K. 1996. Incidence and Distribution of major potato diseases in 1993 and 1994 off season in central Ethiopia (Abstrct). In: $4^{\text {th }}$ Annual Conference of Plant Protection Society of Ethiopia May 1996, Addis Ababa, Ethiopia.

Bekele, B., E. Abate,A.Asefa and M.Dickinson . 2011. Incidence of Potato Viruses and Bacterial wilt 
disease in the West Amhara sub-region of Ethiopia. Journal of Plant Pathology 93(1): 149-157.

Bekele, K. and L. Berga. 2001. Effects of preceding crop, variety and post emergence cultivation (hilling) on the incidence of bacterial wilt. PP 516-523 in Root Crops in the $21^{\text {st }}$ Century. Proceedings of the Seventh Triennial Symposium of the International Society for Tropical Root Crops-Africa Branch (ISTRC-AB). International Conference Center. 11 17 Oct 1998, Cotonou, Benin.

Berga, L., K. Bekele and R.Kakuhenzire. 2000. Integrated control potato bacterial wilt in Eastern Africa. The experience African Highland Initiative, International Potato Center, CIP.

Bias, H.P. 2004. How plant communicate using the underground information super highway. Trends in Plant Science 9 (2): 26-32.

Biratu, K.S., T. Selvaraj and T. Hunduma. 2013.In vitro Evaluation of Actinobacteria against Tomato Bacterial Wilt (Ralstonia solanacearum EF Smith) in West Showa, Ethiopia. J Plant Pathol Microb.4:1-9.

Boshou, L. 2005. A broad review and prospective on breeding for resistance to bacterial wilt. In: Allen C, Prior P, Hayward AC (Eds.), Bacterial wilt disease and the Ralstonia solanacearum species complex. The American Phytopathological Society. St. Paul, Minnesota, USA. pp. 225-238.

Buddenhagen, I. and A. Kelman. 1964. Biological and physiological aspects of bacterial wilt caused by Pseudomonas solanacearum. Annual Review of Phythopathology 2: 203-230.

Buddenhagen, I., L. Sequeira and A. Kelman.1962. Designation of races in Pseudomonas solanacearum. Phytopathology 52: 726.

Ciampi-Panno, L., C. Fernandez,P. Bustamante, N. Andrade , S. Ojeda and A.Conteras.1989. Biological control of bacterial wilt of potatoes caused by Pseudomonas solanacearum Am. Potato J., 66:315-332.

Cook, D and L. Sequeira. 1994. Strain differentiation of Pseudomonas solanacearum by molecular genetic methods. P. 77-94: In: G. L. Hartman and A. C. Hayward, (eds.). Bacterial Wilt: The Disease and Its Causative Agent, Pseudomonas solanacearum. CAB International, Wallingford, United Kingdom.

Coutinho, T. 2005. Introduction and Prospects of the survival of $R$. solanacearum. In: Allen C, Prior P,
Hayward AC, (Eds.). Bacterial Wilt Disease and the Ralstonia solanacearum Species Complex, American Phytopathological Society St. Paul, Minnesota USA. pp. 29-38.

Dahal, D., A. Pich, H.P. Braun and K. Wydra. 2010. Analysis of cell wall proteins regulated in stem of susceptible and resistant tomato species after inoculation with Ralstonia solanacearum: a proteomic approach. Plant Mol. Biol. 73:643-658.

Dannon, E and K. Wydra .2004. Interaction between silicon amendment, bacterial wilt development and phenotype of Ralstonia solanacearum in tomato genotypes. Physiological and Molecular Plant Pathology 64: 233-243.

Dasgupta, S., C. Meisner, D. Wheeler, K. Xuyen and N.T Lam .2007. Pesticide poisoning of farm workersimplications of blood testresults from Vietnam. Int. J. Hyg. Environ. Health 210:121-132.

Denny, T.P.2006. Plant Pathogenic Ralstonia species. p. In: Gnanamanickam SS (Ed.). Plant Associated Bacteria, Springer, The Netherlands. pp. 573-644

Dereje, G., W. Gebremedhin and K. Bekele. 2014. Bacterial Wilt: an Emerging Threat to Ethiopian Potato Industry. In: Seed Potato Tuber, Production and Dissemination Experiences, Challenges and Prospects. (Eds. Gebremedhin W, Schulz S, Baye B). pp 211-222. Proceedings of the National Workshop on Seed Potato Tuber Production and Dissemination, 12-14 March 2012, Bahir Dar, Ethiopia.

Diogo, R.V.C and K.Wydra. 2007. Silicon-induced basal resistance in tomato against Ralstonias olanacearum is related to modification of pectic cell wall polysaccharide structure. Physiology and Molecular Plant Pathology. 70: 120-129.

Dong, C., X, Zeng and Q. Liu.1999. Biological control of tomato bacterial wilt with avirulent bacterinogenic strain of Ralstonia solanacearum . Journal of Science of China Agricultural University 20:1-4.

EARO. Ethiopian Agricultural Research Organization. 2000. Plant Pathology Research Strategy, Ethiopian Agricultural Research Organization (EARO), Addis Ababa.

EARO. Ethiopian Agricultural Research Organization. 2002. Ethiopian Agricultural Research organization (EARO). Annual report for 2000, Addis Ababa, Ethiopia. 
Edwards-Jones, G. 2008. Do benefis accrue to 'pest control' or'pesticides?': a comment on Cooper and Dobson. Crop Prot. 27:965-967.

Elphinstone, J.G. 2005. The current bacterial wilt situation: A global overview. In: Allen C, Prior P, Hayward AC (Eds.). Bacterial Wilt Disease and the Ralstonia solanacearum Species Complex. American Phytopathological Society, St. Paul, Minnesota U.S.A. pp. 9-28.

Elphinstone, J.G., H.M. Stanford and D.E Stead. 1998. Detection of Ralstonia solanacearumin potato tubers, Solanum dulcamara, and associated irrigation water pp. 133-139.In: Prior P, Allen, C and J.G. Elphinstone (eds.) Bacterial Wilt Disease: Molecular and Ecological Aspects. Springer, Berlin, Germany.

EU (European Union). 2003.Ralstonia solanacearum: EPPO quarantine pest. Prepared by CABI and EPPO under the contract 90/399003.

Farag, N.S., F.G. Fawzi, S.I.A. El-Said and M.S. Mikhail.1986. Streptomycin in relation to potato brown rot control. Acta Phytopathologica Entomologica Hungarica 21: 115-122.

Fegan, M and P.Prior . 2006. Diverse members of the Ralstonia solanacearum species complex cause bacterial wilts of banana. Australian Plant Pathology 35: 93-101.

Fegan, $M$ and P.Prior. 2005. How complex is the "Ralstonia solanacearum species complex"? In: Allen C, Prior P, Hayward AC (Eds.), Bacterial wilt disease and the Ralstonia solanacearum species complex .American Phytopathological Society, St. Paul, MN USA. pp.449-461.

Fortnum, B.A and S.B Martin. 1998. Disease management strategies for control of bacterial wilt of tobacco in the southeastern USA, p. 394-402. In P. Prior, C. Allen, and J. Elphinsone (ed.), Bacterial Wilt Disease: Molecular and Ecological Aspects. Springer. Heidelberg, New York

Fortnum, B.A. 2001. Disease Management. In: South Carolina Tobacco Growers Guide. Gooden DT (Ed.) Co-operative Extension Service, Clemson, SC, USA. pp. 38-59.

French, E.R.1994. Integrated control of bacterial wilt of potatoes, CIP Circular. 20: 8-11.

Gadeva, P and B. Dimitrov. 2008. Genotoxic effects of the pesticides Rubigan, Omite and Rovral in root- meristem cells of Crepiscapillaris L. Mutat. Res. 652:191-197.

Gebremedhin, W.G., S.Astede, G. Endale ,T. Agaje, K. Bekele, L. Yohannes and B. Kiflu. 2006. Transforming the traditional potato production through improved technologies in the central highlands of Ethiopia. PP 159-168 in Successes within value chain, Tsedeke Abate (ed). EIAR, Addis Ababa.

Genin, S and C. Boucher. 2004. Lessons learned from the genome analysis of Ralstonia solanacearum. Annual Review Phytopathology 42: 107-134.

Getachew, A., F. Chemeda, A. Seid and K. Wydra. 2009. Aggressiveness of Ralstonia solanacearum Strains and Evaluation of Tomato Genotypes for Resistance. Pest Management Journal of Ethiopia 13:12-21

Getachew, A., F. Chemeda, A. Seid and K. Wydra. 2011. Effects of soil Amendment on bacterial wilt caused by Ralstonia solanacerum and tomato yields in Ethiopia, Journal of Plant Protection Research 51 (1): 72-76,

Getachew, A.H. 2009. Occurrence, Pathogen characterization and Evaluation of disease management options for tomato bacterial wilt (Ralstonia solanacearum) in major tomato growing areas of Ethiopia, $\mathrm{PhD}$, Dissertation, Haramaya University, Ethiopia. .pp. 201.

Hartman, G.L and J.G. Elphinstone. 1994. Advances in the control of Pseudomonas solanacearum race 1 in major food crops. In: Hayward AC, Hartman GL (Eds.) Bacterial wilt: The disease and its causative agent Pseudomonas solanacearum. Wallingford, UK: CAB International. pp.157-177.

Haverkort, K., F. van Koesveld, H. Schepers , J. Wijnands , R. Wustman and X. Zhang. 2012. Potato prospects for Ethiopia: on the road to value addition. The Netherlands, Wageningen UR, pp 66.

Hayward, A.C .1991. Biology and epidemiology of bacterial wilt caused by Pseudomonas solanacearum. Phytopathology 29: 65-87.

Hayward, A.C .1994. The hosts of Pseudomonas solanacearum: In: Hayward AC, Hartman GL (Eds.) Bacterial wilt: The Disease and its Causative Agent, Pseudomonas solanacearum. Wallingford, UK: CAB International. pp. 9 -24.

Hayward, A.C. 1994. Systematic and phylogeny of Pseudomonas solanacearum and Related Bacteria. 
In: Hayward AC, Hartman GL (Eds.) Bacterial Wilt: The disease and its causative agent Pseudomonas solanacearum CAB International, Oxford, UK. pp. 123-135

Hayward, A.C. 2000.Ralstonia solanacearum. In: Lederbergerg J. (Ed.) Encyclopedia of Microbiology Vol.4 San Diego, California. Academic Press. pp.32-42.

Hayward, A.C. 2005. Research on bacterial wilt: A prospective on international linkages and access to the literature. In: Allen C, Prior P, Hayward AC (Eds.) Bacterial Wilt Disease and the Ralstonia solanacearum Species Complex. American Phytopathological Society, St. Paul, Minnoseta, USA. pp.1-6.

Hayward, A.C., L. Sequeira, E.R. French, E.L. Nashar and H.M.U.Nydegger.1992. Tropical variant of biovar 2 of Pseudomonas solanacearum. Phytopathology 82: 608.

Hayward, A.C.1964.Characteristics of Pseudomonas solanacearum. Journal of. Applied. Bacteriology 27: 265-277.

He, L., L. Sequeiraand A. Kelman. 1983. Characteristics of strains of Pseudomonas solanacearum from China. Plant Disease 67:1357-1361.

Janvier, C., F. Villeneuve, C. Alabouvette, V. EdelHermann, T. Mateille, and C. Steinberg. 2007.Soil health through soil disease suppression: Which strategy from descriptors to indicators? Soil Biol. Biochem. 39:1-23.

Kang, Y., G.Mao, C. Lu and L.He. 1995. Biological control of bacterial wilt of tomato by extracellular protein defective mutant of Pseudomonas solanacearum. Acta Phytopathology Singapore 22:287-288.

Katafiire, M., E. Adipala, B. Lemaga, M. Olanya , R. ElBedewyand P. Ewell. 2005. Management of bacterial wilt of potato using one-season rotation crops in southwestern Uganda. In: Allen C, Prior P, Hayward AC (Eds.) Bacterial Wilt Disease and the Ralstonia solanacearum Species Complex? American Phytopathological Society, St. Paul, Minnesota USA. pp. 197-203.

Kelman, A. 1998. One hundred and one years of research on bacterial wilt. In: P. Prior P, Allen C, Elphinstone J (Eds.) Bacterial Wilt Disease. Molecular and Ecological Aspects, Springer-Verlag, Heidelberg. Germany. pp. 1-5.
Kelman, A. 1998. One hundred and one years of research on bacterial wilt. In: Prior P, Allen C, Elphinstone J (Eds.) Bacterial wilt disease. Molecular and ecological Aspects. Springer-Verlag, Heidelberg, Germany. pp. 1-5.

Kelman, A., G.L Hartman and A.C. Hayward .1994. Introduction. In: Hayward AC, Hartman GL (Eds.) Bacterial Wilt: the disease and its causative agent, Pseudomonas solanacearum. CAB International, Wallingford, United Kingdom. pp. 1-7.

Kinyua, Z. M., J.J Smith, C. Lung'aho, M. Olanya and S.Priou. 2001.On-farm success and challenges of producing bacterial wilt free tubers in seed plots in Kenya. African Crop Science Journal, 9:279-285.

Knapp, S., L. Bohs, M. Nee and D.M. Spooner. 2004. Solanaceae-A model for linking genomics with biodiversity. Comparative and Functional Genomics 5: 285-291.

Kurabachew, $\mathrm{H}$ and K. Wydra. 2014.Induction of systemic resistance and defense related enzymes after elicitation of resistance by rhizobacteria and silicon application against Ralstonia solanacearum in tomato (Solanum lycopersicum). Crop Protection 57: 1-7.

Kurabachew, H and K.Wydra . 2013. Characterization of plant growth promoting rhizobacteria and their potential as bio-protectant against tomato bacterial wilt caused by Ralstonia solanacearum. Biological Control 67 (1): 75-83.

Kurabachew, H., A. Fasil and H.Yaynu. 2007. Evaluation of Ethiopian isolates of Pseudomonas fluorescens as biocontrol agent against Potato bacterial wilt caused By Ralstonia (Pseudomonas) solanacearum. Acta Agriculturae Slovenica 90 (2): 125-135.

Kurabachew, H.,F. Stahl and K. Wydra .2013. Global gene expression of rhizobacteria-silicon mediated induced systemic resistance in tomato (Solanum lycopersicum) against Ralstonia solanacearum. Physiological and Molecular Plant Pathology 84: 44-52.

Lemaga, B., D. Siriri and P. Ebanyat.2001b. Effect of soil amendments on Bacterial Wilt incidence and yield of potatoes in Southwestern Uganda. African Crop Science Journal 9 (1): 267-278.

Lemaga, B., R. Kakuhenzine, B. Kassa , P.T. Ewell and S.Priou. 2005. Integrated control of potato bacterial wilt in eastern Africa: the experience of African highlands initiative, p. 145-158. In C. 
Allen, P. Prior and A.C. Hayward (ed.), Bacterial Wilt Disease and the Ralstonia solanacearum Species Complex. American Phytopathological Society Press, St. Paul, MN.

Lemaga, B., R. Kanzikwera, R. Kakuhenzire , J.J Hakiza and H.Manzi. 2001a. Effect of crop rotation on bacterial wilt incidence and potato tuber yield. African Crop Science Journal 9 (1): 257-266.

Lemessa F, Zeller W. (2007) Isolation and characterization of Ralstonia solanacearum strains from Solanaceae crops in Ethiopia. Journal of Basic Microbiology 47: 40-49.

Lemessa, F., W. Zeller and D. Negeri. 2010.Genetic diversity among strains of Ralstonia solanacearum from Ethiopia assessed by repetitive sequencebasedpolymerase chain reaction (rep-PCR). EJAST 1(1)17-27.

López, M.M and E.G. Biosca. 2005. Potato bacterial wilt management: new prospects for an old problem, p. 205-224. In C. Allen, P. Prior, and A.C. Hayward (ed.), Bacterial Wilt Disease and the Ralstonia solanacearumSpecies Complex. American Phytopathological Society Press, St. Paul, MN.

Mansfid, J., S. Genin, S. Magor, et al..2012. Top 10 plant pathogenicbacteria in molecular plant pathology. Mol. Plant Pathol. 13:614-629.

McCarter, S.M.1991. Bacterial wilt. In: Jones JB, Jones JP, Stall RE, Zitter TA (Eds.) Compendium of tomato diseases. American Phytopathological Society. St. Paul, Minnesota, USA. pp.28-29.

Michel, V.V. and T.W. Mew. 1998. Effect of soil amendment on the survival of Ralstonia solanacearum in different soils. Phytopathology 88:300-305.

Moffett, M.L and A.C. Hayward.1980. The role of weed species in the survival of Pseudomonas solanacearum in tomato cropping land. Australian Plant Pathology 9: 6-8.

Muthoni,J., H. Shimelis and R. Melis.2012.Management of Bacterial Wilt [Rhalstonia solanacearum Yabuuchi et al., 1995] of Potatoes: Opportunity for Host Resistance in Kenya Journal of Agricultural Science.4 (9):64-78.

Nakaho, K., H. Inoue,T. Takayama and H. Miyagawa. 2004. Distribution and multiplication of Ralstonia solanacearumin tomato plants with resistance derived from different origins. J. Gen. Plant Pathol. 70:115-119.
NAPPO. 2001.Ralstonia (Pseudomonas) solanacearum (E. F. Smith, 1896) Yabuuchi et al. (1995) race 3 biovar 2. Phytosanitary Alert System. Available: http://www.pestalert.org. Accessed: 01-06-2006.

OEPP/EPPO.2004.Ralstonia solanacearum. European and Mediterranean Plant Protection Organization Bulletin 34: 173-178.

Olsson, K. 1976. Over-wintering of Pseudomonas solanacearum in Sweden, In: Sequeira L, Kelman A (Eds.) Proceedings of the First International Planning Conference and Workshop on the ecology and control of bacterial wilt caused by Pseudomonas solanacearum. North Carolina State University. Raleigh, USA. pp.105-109.

Pegg, K. and M.Mofett. 1971. Host range of ginger strain of Pseudomonas solanacearum in Quuensland. Australian Journal of Experimental Agriculture and Animal Husbandry. 11:696-698.

Persley, G.J. 1986. Ecology of Pseudomonas solanacearum, the causal agent of bacterial wilt. In: Persley GJ (Ed.) Bacterial wilt disease in Asia and the South Pacific. Canberra: ACIAR Proceedings No.13. pp: 71-76.

Ray, D.K., N.D. Mueller, P.C. West, PC and J.A. Foley.2013. Yield trends are insufficient to double global crop production by 2050.PLoS One 8:e66428.

Saddler. G.S. 2005. Management of Bacterial wilt Disease. In: Allen C, Prior P, Hayward AC (Eds.) Bacterial Wilt Disease and Ralstonia solanacearum Species Complex, The American Phytopathological Society. St.Paul Minnesota, USA. pp.121-132.

SPL (Scientific Phytopathological Laboratory). 1981. Progress report for the period January 1980 to December 1980. Ambo, Ethiopia .pp. 97-98.

Stewart, B and Y. Dagnachew . 1967. Index of Plant diseases in Ethiopia. Haileselassie I University, College of Agricultural Experimental Station Bulletin. No. 30. Debrezeit, Ethiopia, p.95.

Stewart,R.B .1956. Some plant disease occurring in Keffa Province, Ethiopia. College of Agriculture Alemaya, Ethiopia

USDA. 2003.Biological control of Fusarium wilt and other soil-borne pathogenic fungi. http://www.ars.usda.gov/research/projects/proj ects.htm?ACCN_NO=406590\&fy $=2003$

Van Elsas, J.D., P. Kastelein, P.M. deVries and L.S. Van der Overbeek. 2001.Effects of ecological factors on the survival and physiology of Ralstonia 
solanacearum biovar 2 in agricultural drainage water. Microbiology 47: 842-854.

Vasse, J., P. Frey and A. Trigalet. 1995. Microscopic studies of intercellular infection and protoxylem invasion of tomato roots by Pseudomonas solanacearum. Molecular Plant Microbe Interaction 8: 241-251.

Wang, J.F and C.H Lin. 2005. Colonizing capacity of Ralstonia solanacearum tomato strains differing in aggressiveness on tomato and weeds. In: Allen C, Prior P,.Hayward AC (Eds.) Bacterial wilt disease and the Ralstonia solanacearum species complex. The American Phytopathological Society, St.Paul Minnesota, USA. Pp. 73-79.

Whipps, J. 2001. Microbial interactions and biocontrol in the rhizosphere. J. Exp. Bot. 52:487-511.

Whipps, J.M and B. Gerhardson. 2007. Biological pesticides for control of seed- and soil-borne plant pathogens, p. 479-501. In J.D. VanElsas, J.D. Jansson, and J.T. Trevors (ed.), Modern Soil Microbiology 2nd Edition. CRC Press, FL

Wicker, E., L. Grassart, R. Coranson-Beaudu ,D. Mian ,C. Guilbaud and M. Fegan. 2007. Ralstonia solanacearum Strains from Martinique (French West Indies) Exhibiting a New Pathogenic Potential. Applied and Environmental Microbiology 71: 6790-6801.

Yabuuchi, E., Y. Kosako, I. Yano , H. Hotta and Y. Nishiuchi. 1995. Transfer of two Burkholderia and an Alcaligenes species to Ralstonia General Nov: proposal of Ralstonia picketti (Ralston, Palleroni and Doudoroff 1973) comb. Nov., Ralstonia solanacearum (Smith 1896) comb. Nov. and Ralstoniaeutropha (Davis 1969) comb. Nov. Microbiology and Immunology 39: 897-904.

Yabuuchi, E., Y. Kosako, H. Oyaizu , I. Yano, H. Hotta , Y. Hashimoto, T. Eaki and T. Arakawa. 1992. Proposal of Burkholderiagen. nov. and transfer of seven species of the genus Pseudomonas group II to the new genus with the type species Burkholderia cepacia (Palleroni and Holmes 1981) comb. nov. Microbiology and Immunology 36:1251-1275.

Yadessa,G.B.,A.H.C. van Bruggen and F.I.Ocho.2010. Effects of different soil amendments on bacterial wilt caused by Ralstonia solanacearum and on the yield of tomato. Journal of Plant Pathology 92 (2): 439-450.

Yaynu, H and A.P. Korobko. 1986. Incidence of potato bacterial wilt in some potato growing areas of Ethiopia. In Proceedings of $15^{\text {th }}$ annual meeting of Ethiopian Phytopathological Committee (EPC).1314 March, 1990, Addis Ababa, Ethiopia.

Yaynu, H. 1989. Characteristics of isolates of Pseudomonas solanacearum in Ethiopia. Ethiopian Journal of Agricultural Science 11: 7-13.

Yuliar, Y.A. Nion and K. Toyota . 2015. Recent Trends in Control Methods for Bacterial Wilt Diseases Caused by Ralstonia solanacearum. Minireview. Microbes Environ. Vol. 30, No. 1, 1-11. 